\title{
What are the Recent Questions of Public about Workplace?
}

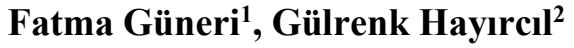 \\ ${ }^{1}$ Hemisf4ire Design School, Université Catholique de Lille, France \\ ${ }^{2}$ Universität Duisburg-Essen, Germany
}

\begin{abstract}
This paper presents the short results of one-time data observation about a very actual subject. Workplaces are strongly impacted by the confinements due to Covid-19. The research focus is to get public's views momentously and interpret them with a semiotic look. Finally, the results bring some research propositions and a conceptual model.
\end{abstract}

KEY WORDS: questions, workplace, conceptual model, Covid-19

\section{INTRODUCTION:}

Answerthepublic.com. shares any public's questions about various subjects. In this study we will present the public's questions about "workplace". The research focus is to relieve what kind of inquiries people have actually where the work quality and measures are completely changed due to Covid-19. The study has been realised by a data observation and following semiotic approaches to the results. Finally, research propositions and a preliminary conceptual model created with a hope to provide an inspiring material to future research.

\section{DATA OBSERVATION:}

On 08/02/2021 around 21:30 “workplace” had been typed into the research motor of answerthepublic.com. There wasn't any specific reason to choose this date and this hour. There wasn't also any target country. In a second, 376 results about workplaces have been presented. The results were in five categories

a. 80 Questions related to workplaces (Figure 1)

b. 56 Prepositions connected to workplaces (Figure 2)

c. 36 Comparisons concerning workplaces (Figure 3)

d. 196 Alphabetical listings about workplaces

e. 8 Related words to workplaces (Figure 4)

In this study only a, b, c and e will be presented. Only reason is that the study has focused on visual presentations of data. Alphabetical listings which present the results in an index could be checked on answerthepublic.com.

\section{RESULTS:}

The visual results are shown on pages between 4-6.

\section{a. 80 Questions:}

The eighty questions related to the workplaces surround the human being. The human being is first surrounded by WH questioning words such as "why, what, when who, where, which" as well as other words such as "are, can, how". This first circle is constructed of eight words which each of them lead to other ten questions. The second circle is therefore, constructed of the eighty questions that are born from these eight words. As a result, the human being is imprisoned in the circle of questions that he or she has to manage at the workplace. There is no way without fulfilling the tasks and finding solutions to the circle of questions.

\section{b. 56 Prepositions:}

The second figure depicts a human being firstly surrounded by seven words which are "near, can, without, is, for, to, with". The first circle constructed of seven words lead to the second circle. Each word in the first circle give birth to eight sentences. It is as if the first circle leading to the second circle is gaining their strength and energy from the human being. All the strings are connected to the human being and are life draining. The human being has to be strong enough to be able to withstand the tough tasks that he or she has to manage at the workplace. 


\section{International Journal of Current Science Research and Review}

ISSN: 2581-8341

Volume 04 Issue 03 March 2021

DOI: 10.47191/ijesrr/V4-i3-09, Impact Factor: 5.825

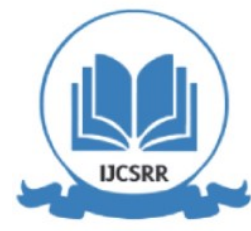

Www.ijcsrr.org

\section{c. $\quad 36$ Comparisons:}

The human being is now dealing with a lighter first circle which is made of five comparative words such as "vs, like, or, and, versus". The first circle leads to the second circle, while some comparative words construct eight others construct only an half amount of sentences. At this figure the human being is as if he or she himself is creating these circles: There are things and issues that the human being has to deal with but it is his or her own thoughts that construct these circles. These comparisons are depicting his or her own brainstorming during the day of a workplace.

\section{d. 8 Related:}

The last picture is depicting a human being encircled with eight words. The circle is not agonizing the human being in the middle. In contrast, it is as if the human being is in harmony with the circles themselves. He or she has accepted that he or she has to be at a workplace. The workplace and its definition is not a prison but a circle that protects the human being. Within the workplace the human being is gaining strength and power. Manageable tasks construct a creative environment and an environment where the human being is able to breath and bloom.

\section{RESEARCH PROPOSITIONS:}

According to the semiotic interpretations above we bring some research questions for the future research about workplace subject: a. 80 Questions: What are the most common questions to which white or blue collars cannot find an answer on their own? What are the roles of managers to enlighten these interrogations?

b. 56 Propositions: When the employees weaken due the tough tasks how the managers could increase the motivation by reorganising the duties? In which ways the capacity of each employee should be measured and the tasks should be shared fairly? c. 36 Comparisons: How managers could identify the right moments to set up an empathy with their collaborators? Which stimulators could be useful to help employees to be more expressive about their feelings and thoughts?

d. 8 Related: What are the optimism theories about work environments? What make the workplaces as a second home for the white and blue collars

PRELIMINARY CONCEPTUAL MODEL PROPOSITION: The research propositions below are illustrated by a preliminary conceptual model:

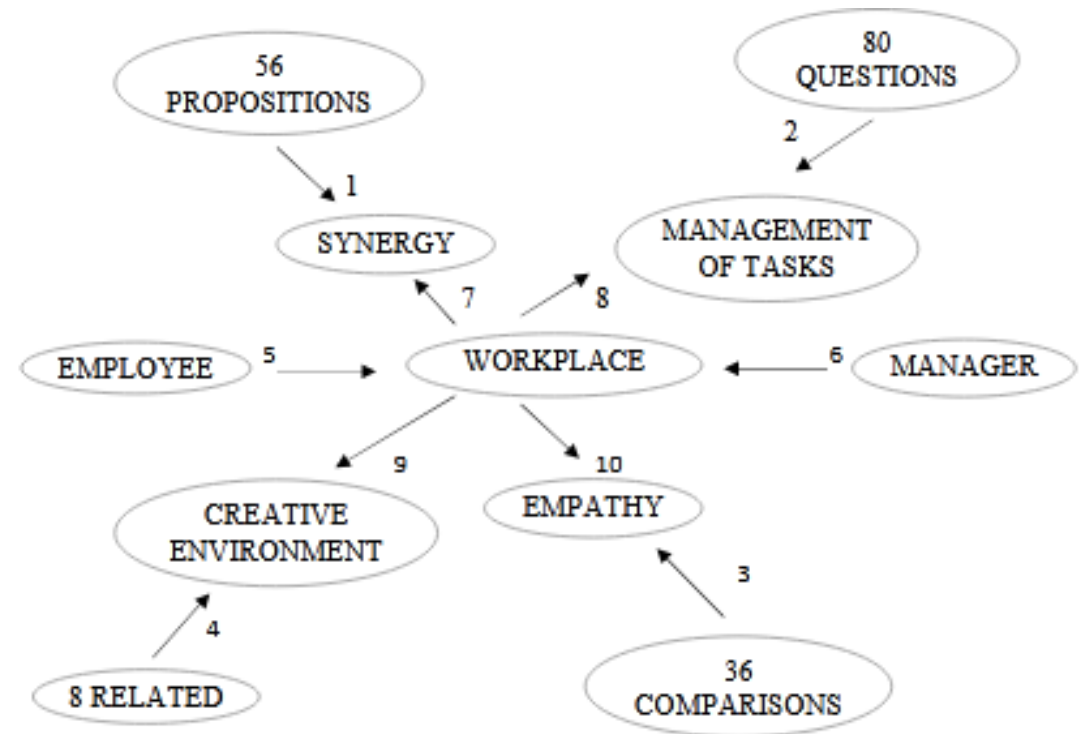

Model 1: A conceptual model of workplace

In the model, numbers 1, 2, 3 and 4 show the causal relationship between public's questions and semiotic interpretations. These are inputs which create outputs of workplaces. The outputs are presented by numbers 7,8, 9 and 10. Finally the main actors who are 


\section{International Journal of Current Science Research and Review}

ISSN: 2581-8341

Volume 04 Issue 03 March 2021

DOI: 10.47191/ijesrr/V4-i3-09, Impact Factor: 5.825

IJCSRR@ 2021

WwW.ijesrr.org

active in the creation of the outputs are employees and managers (Numbers 5 and 6 ). Maslow ${ }^{\mathrm{i}}$ is one of the most important references for similar theories about workplace.

List of Figures:

Figure 1: 80 Questions

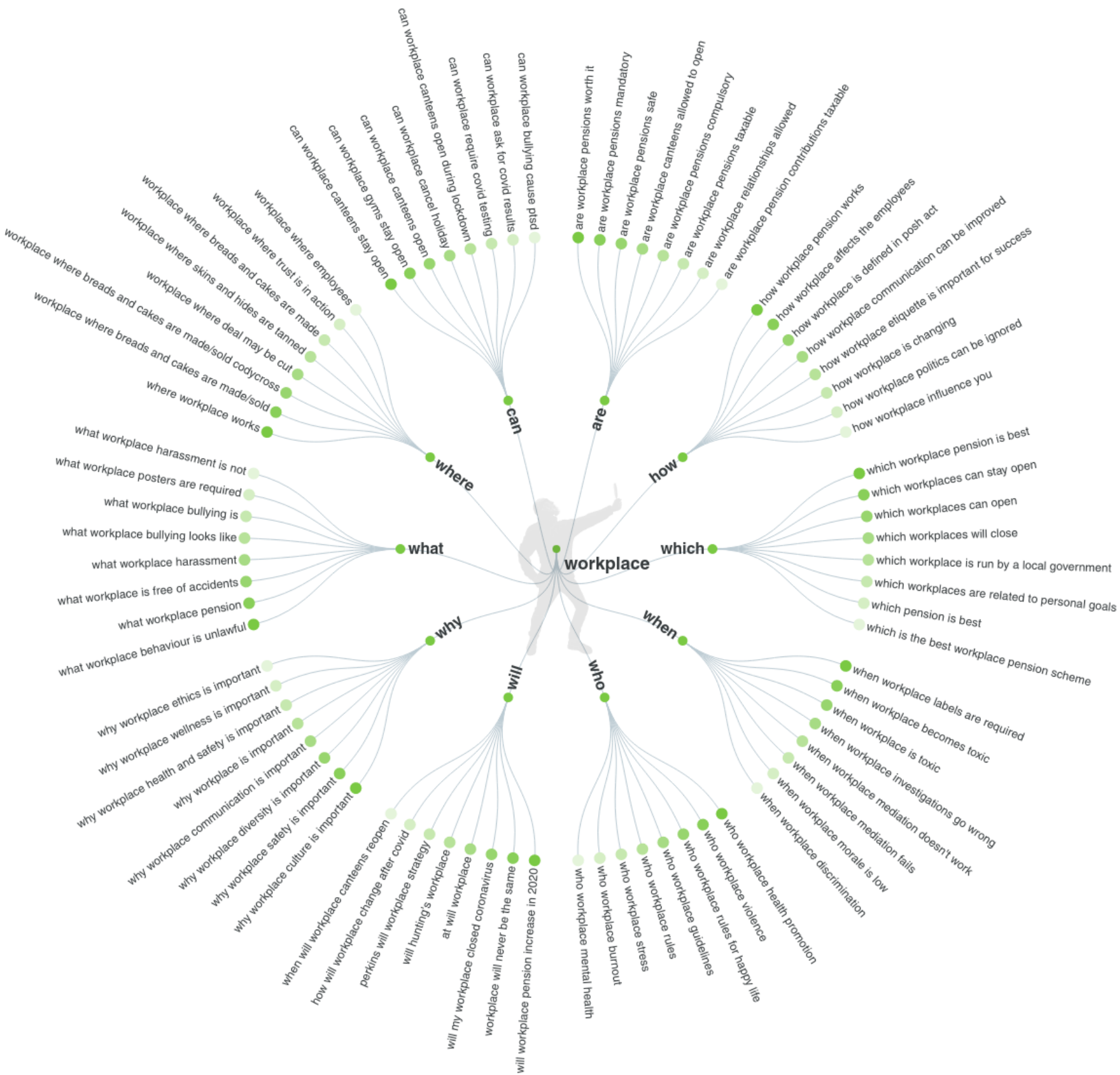


International Journal of Current Science Research and Review

ISSN: 2581-8341

Volume 04 Issue 03 March 2021

DOI: 10.47191/ijesrr/V4-i3-09, Impact Factor: 5.825

IJCSRR@ 2021

www.ijesrr.org

Figure 2: 56 Propositions

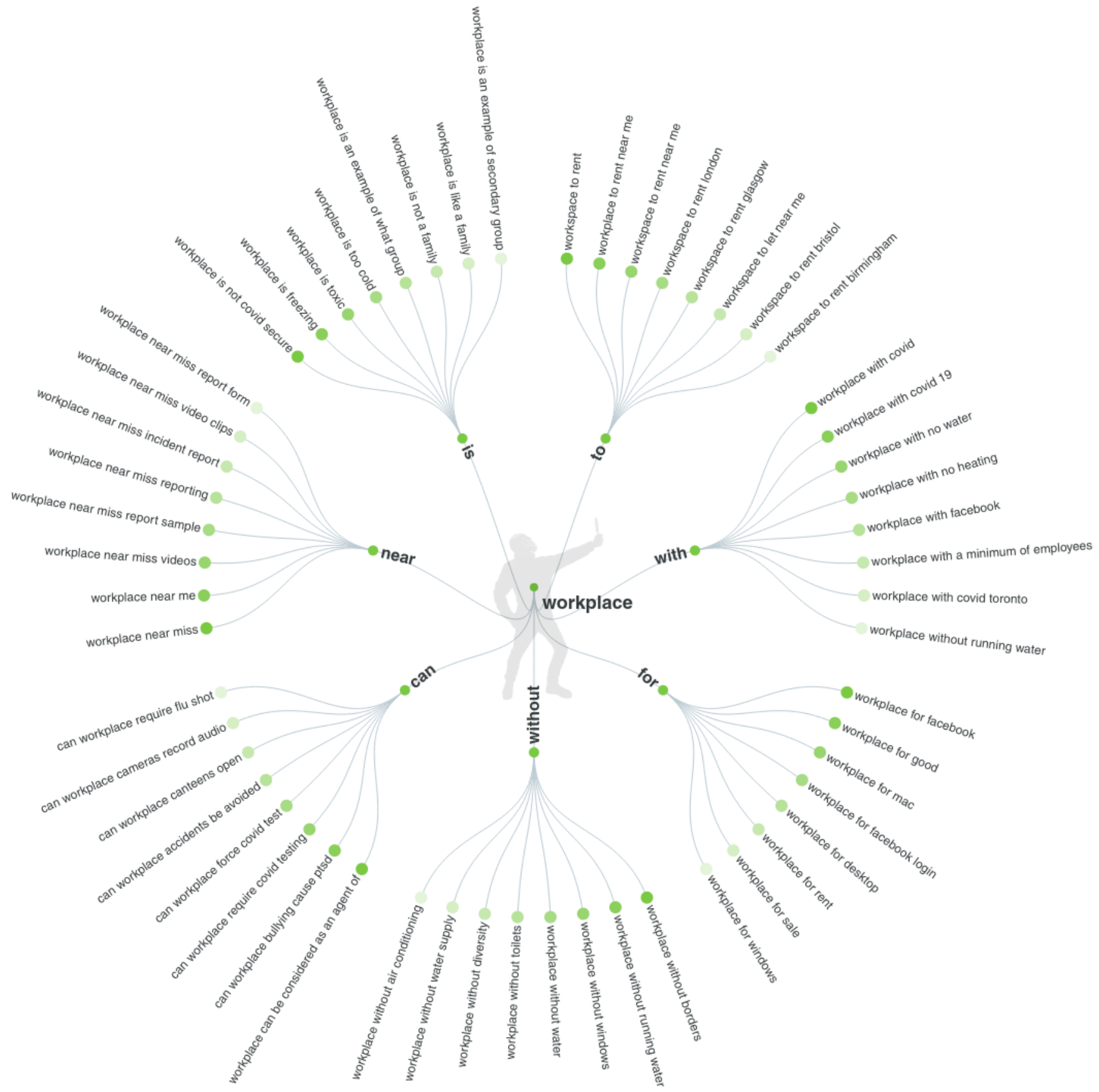


International Journal of Current Science Research and Review

ISSN: 2581-8341

Volume 04 Issue 03 March 2021

DOI: 10.47191/ijesrr/V4-i3-09, Impact Factor: 5.825

IJCSRR@ 2021

www.ijesrr.org

Figure 3: 36 Comparisons
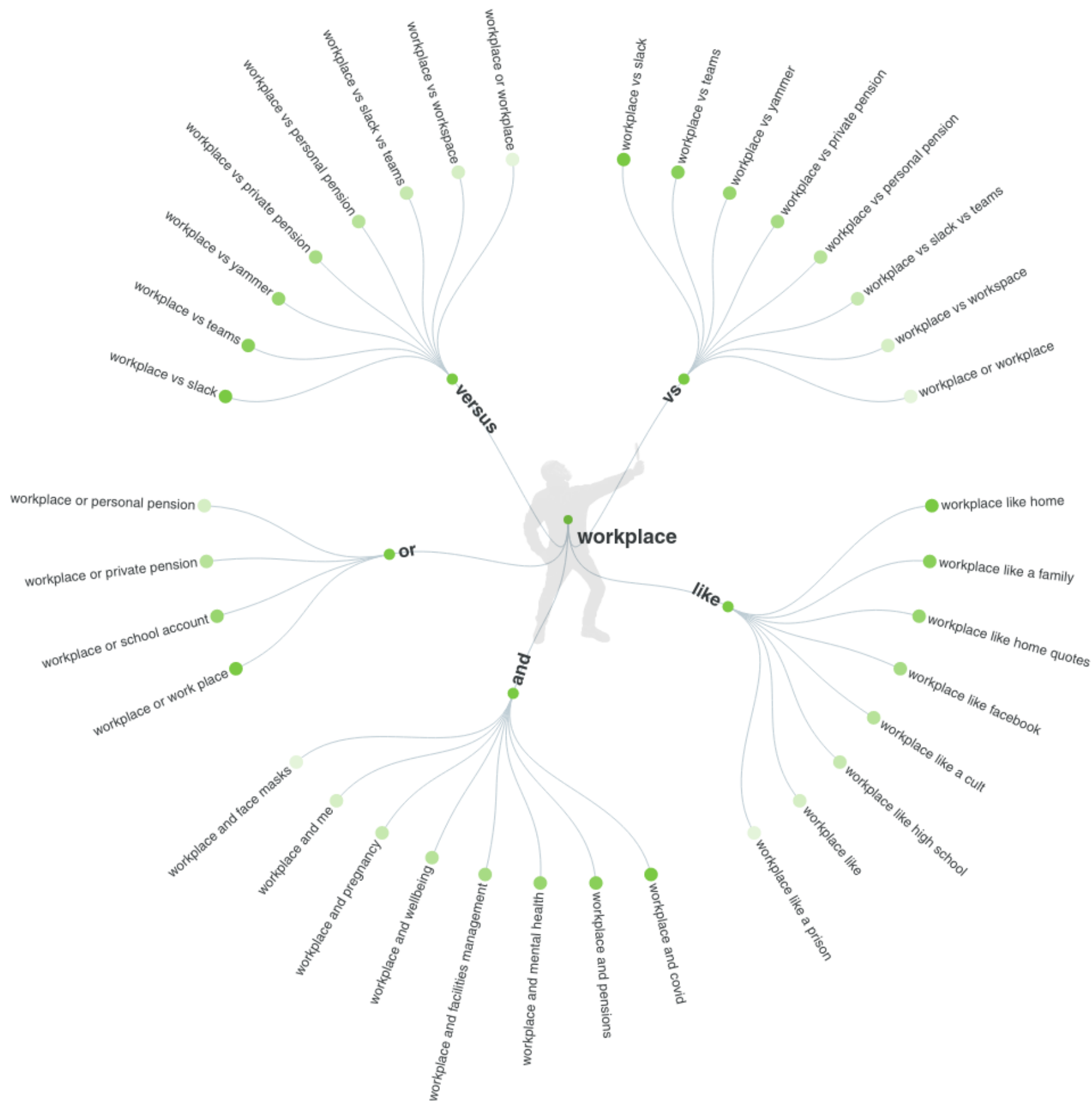
International Journal of Current Science Research and Review

ISSN: 2581-8341

Volume 04 Issue 03 March 2021

DOI: 10.47191/ijcsrr/V4-i3-09, Impact Factor: 5.825

IJCSRR@2021

www.ijesrr.org

Figure 4: 8 Related

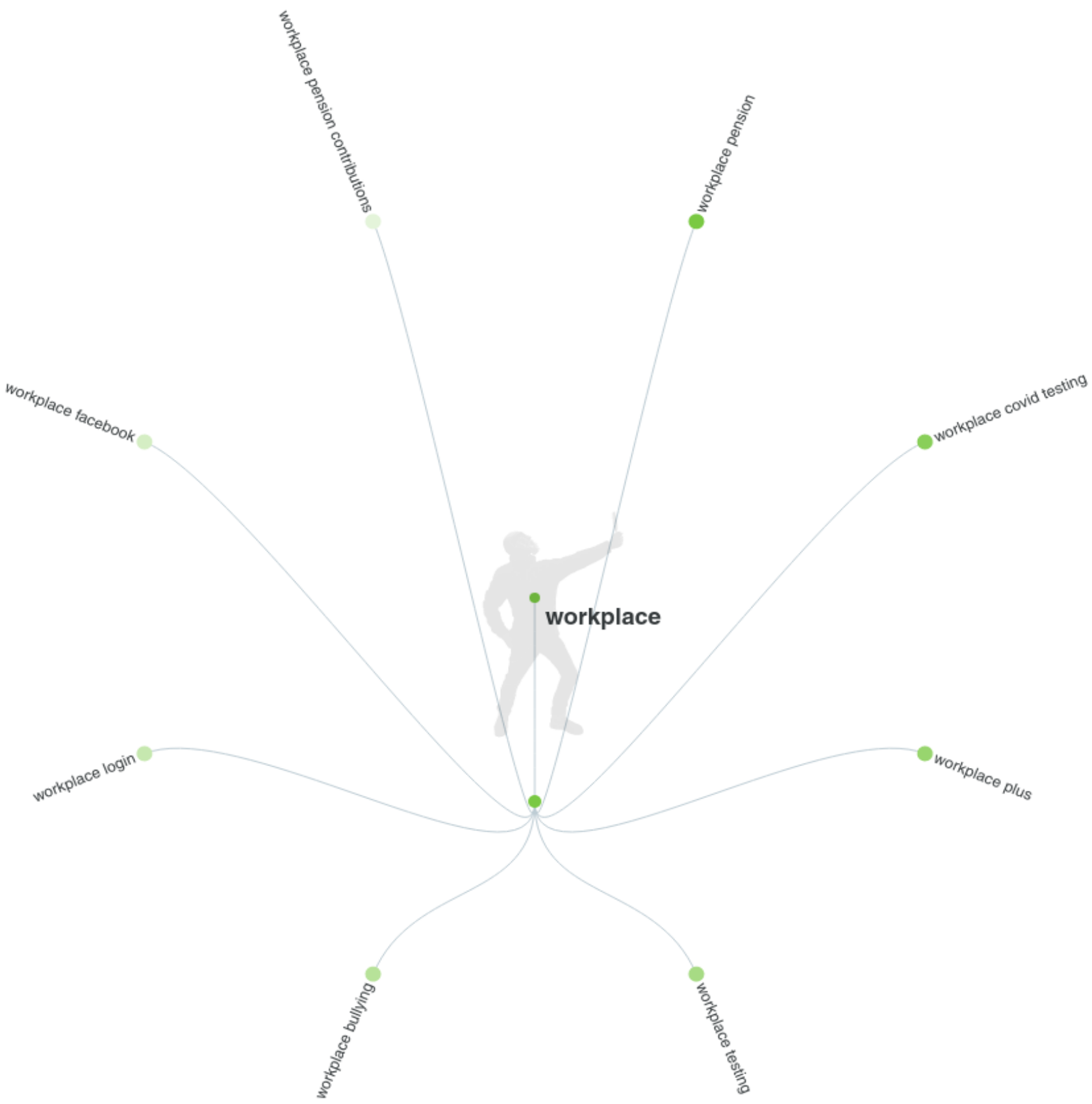

Cite this Article: Fatma Güneri, Gülrenk Haytrcl (2021). What are the Recent Questions of Public about Workplace?. International Journal of Current Science Research and Review, 4(3), 218-223

' https://lesphilosophesduclept.files.wordpress.com/2013/09/abraham-maslow.pdf 